\title{
ABNORMAL CONJUGATION IN SPIROGYRA
}

J. G. B ROW N

\section{(WITH THREE FIGURES)}

Recently while teaching a class in plant histology, the attention of the writer was directed by one of his students to the conjugating cells of Spirogyra shown in the accompanying figures. The material from which the figures were drawn, which answered to WoLLE's

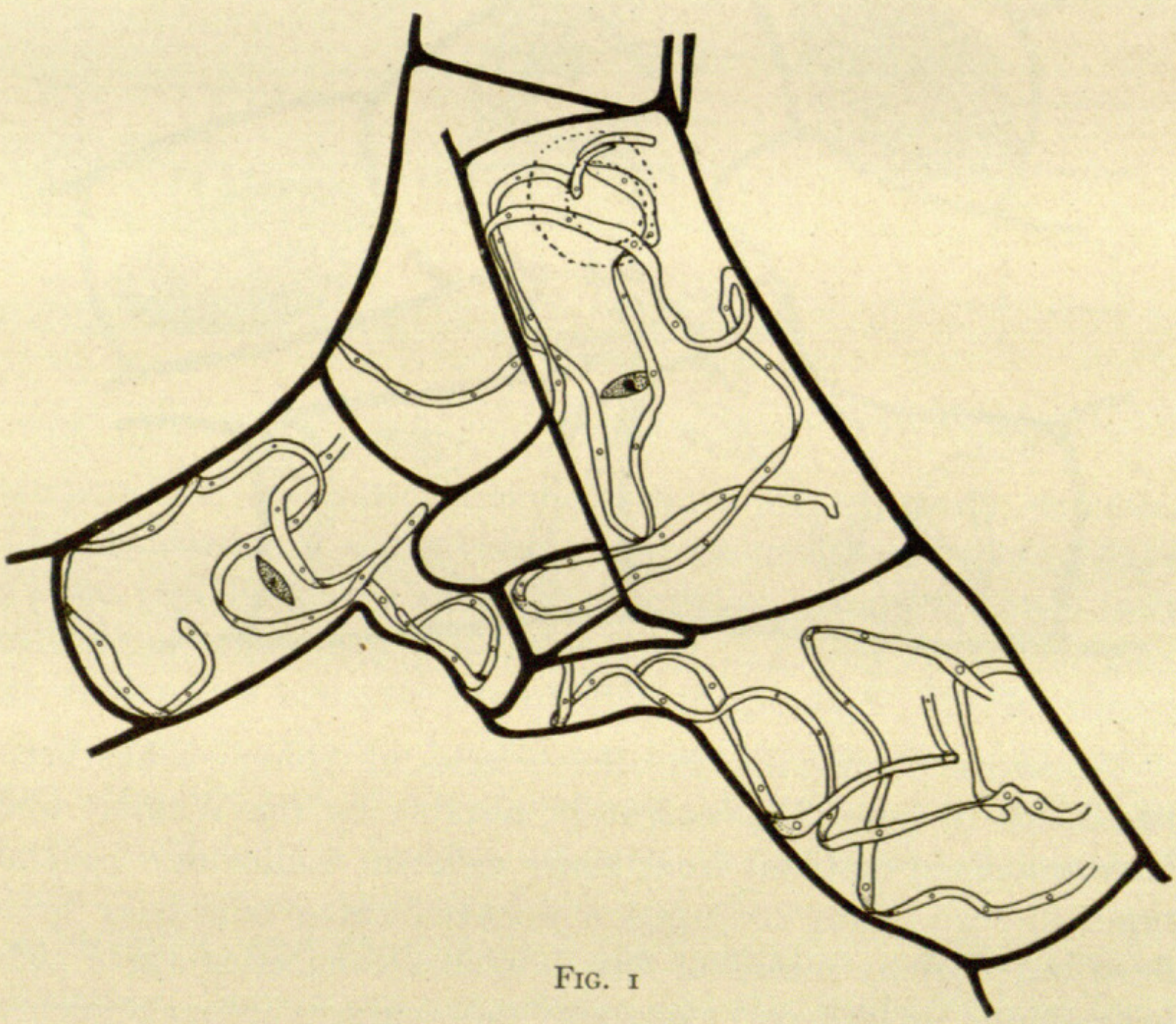

description of $S$. nitida ${ }^{\mathrm{I}}$ was collected in the Rillito River north of Tucson in April I9I7. When they were examined under low power lens, the conjugating cells shown in fig. I presented the appearance of a knot. Upon analyzing the situation, one of the four cells was found to have connections with three others, two with

${ }^{x}$ Wolle, Francis, Fresh-water algae of the United States, p. 217. 
two others, and the fourth with one other. Three of the conjugation branches formed a triple connection, and two other cases of triple connection were found on the same slide. The cells represented in fig. 2 also presented an interesting study in reproduction. One cell was here monopolizing the energies of two cells in an adjacent filament, while its neighbor on each side had resorted to parthenogenesis. Although several slides were examined, nò cases of lateral conjugation were observed.

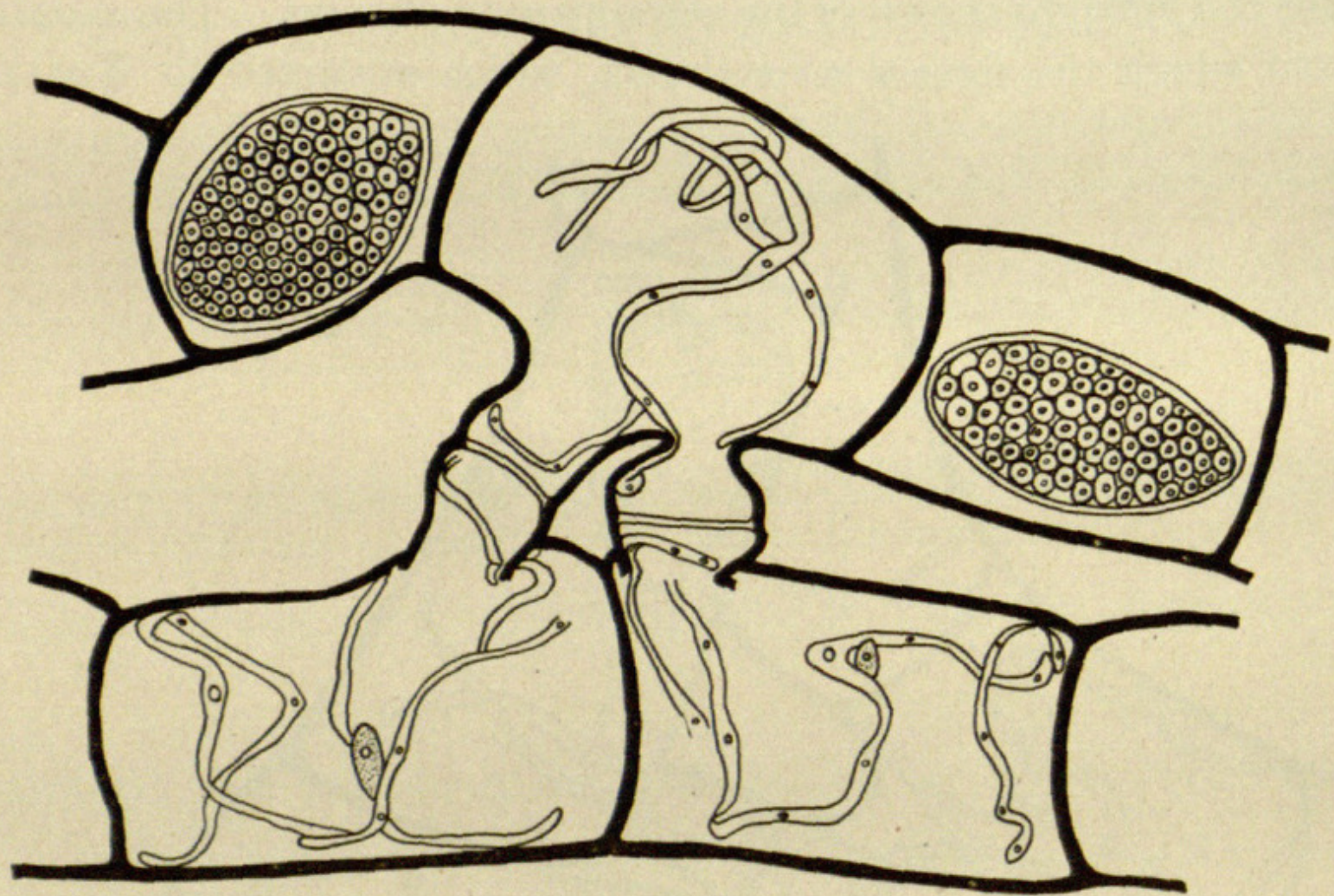

Fig. 2

Abnormal conjugation in other species of Spirogyra has been mentioned by several investigators, notably by the WEsts, ${ }^{2}$ who have examined material from many different countries. Several types of scalariform conjugation between three cells have been described: (a) by means of four branches connecting three cells belonging to two different filaments; $(b)$ by means of four branches connecting three cells belonging to as many different filaments; (c) by means of three branches forming a triple connection. According to the Wests the last type mentioned is very rare. They illustrate a case of triple connection of conjugation branches in $S$. condensata in which one of the three branches has prevented the

${ }^{2}$ West, W. and G. S., Observations on the Conjugatae. Ann. Botany 12:29-58. 1898. 
protoplasts of two of the three cells concerned from fusing. This appears to be a common result, and the large proportion of failures has been interpreted as proving the abnormality of the method. Another illustration included in the paper cited represents a condition in $S$. maxima similar to the one described in this note in fig. 2 for $S$. nitida, excepting the parthenogenetically formed spores. The great profusion of conjugation branches exhibited occasionally by Spirogyra filaments, accompanied by the tendency to form abnormal connections, has been regarded as a response to environmental conditions exceptionally unfavorable for vegetative growth. In this region such external factors as the volume,

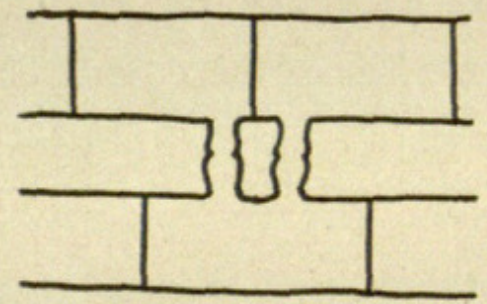

$a$

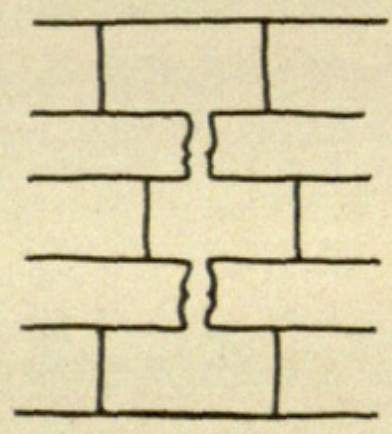

$b$

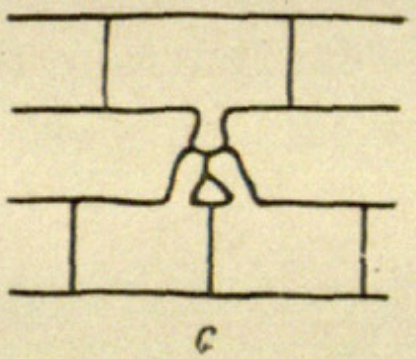

FIG. 3

temperature, and salt content of water are extremely variable. The fluctuation in water volume may be such that in a few days a large, rapidly flowing stream is changed to a trickling brook, then to a series of stagnant pools, then later to a "dry river" carrying its entire flow beneath the surface of the bed. In the winter snow water reaches the foothill and mesa country in a cold condition after showers in the mountains. Floods of this cold fresh water must have a decided influence on the algal vegetation of pools by lowering the temperature and salt concentration, increasing aeration, and thus making the vegetative conditions more favorable. Subsequent evaporation and the "run-off" from local showers increase the salt content to a maximum and again subject algae to unfavorable vegetative conditions, thus bringing on great reproductive activity. The Spirogyra figured in this note was collected in a pool which had gone through a similar cycle of changing conditions. 


\section{$2 \mathrm{BHL}$ Biodiversity Heritage Library}

Brown, J. G. 1918. "Abnormal Conjugation in Spirogyra." Botanical gazette 66(3), 269-271. https://doi.org/10.1086/332334.

View This Item Online: https://www.biodiversitylibrary.org/item/109341

DOI: https://doi.org/10.1086/332334

Permalink: https://www.biodiversitylibrary.org/partpdf/224060

\section{Holding Institution}

Missouri Botanical Garden, Peter H. Raven Library

\section{Sponsored by}

Missouri Botanical Garden

\section{Copyright \& Reuse}

Copyright Status: Public domain. The BHL considers that this work is no longer under copyright protection.

This document was created from content at the Biodiversity Heritage Library, the world's largest open access digital library for biodiversity literature and archives. Visit BHL at https://www.biodiversitylibrary.org. 